Viewpoint

\title{
Realizing the latent potential in the part-time
}

\section{student workforce}

\section{Carl Evans}

Programme Area Leader for Business \& Management, University of St Mark \& St John, Plymouth, UK

\section{Mark Richardson}

Worcester Business School, University of Worcester, Worcester, UK

\section{Corresponding author:}

Carl Evans, Programme Area Leader for Business \& Management, University of St Mark \& St John, Derriford Road, Plymouth PL6 8BH, UK. Email: cevans@marjon.ac.uk.

\footnotetext{
Abstract:

The purpose of this article is to challenge employers to make the best use of the latent potential of their part-time student workforce and to retain this talent post-graduation. The authors report research which shows that increasing numbers of university students are working part-time alongside their degree studies, while at the same time businesses are becoming more explicit about their requirements for graduate entrants, specifying a range of traits, behaviours and soft skills. The authors argue that this developing scenario affords an opportunity for university students working part-time to develop skills and business-related knowledge that are desirable to their respective employers in the longer term. However, the desire to nurture and retain those individuals on graduation appears to be lacking.
} 
This paper concludes by challenging both employers and students to embrace a longer-term perspective for their mutual benefit.

\section{Keywords:}

part-time working, graduate careers, graduate recruitment, managing talent

A growing number of university students in the UK now work part-time alongside their degree studies

(UCAS, 2011). This trend is primarily attributable to financial needs (Richardson et al., 2009), exacerbated by increases in university tuition fees (Boyce and Stone, 2015). Yet this focus on earning while learning in order to survive the financial hardship associated with a period of university study seemingly overlooks the substantial opportunities afforded by the part-time work undertaken. Although these students may well be developing the knowledge, skills and behaviours demanded by employers (Pan and Lee, 2011), the opportunity to keep hold of, nurture and develop them postgraduation is apparently being largely ignored by most employing organizations, so that the graduates pursue careers elsewhere, taking with them valuable organizational experience (Evans et al., 2014). This paper therefore seeks to challenge businesses to make the best use of the latent potential of their part-time student workforce and to retain this talent post-graduation.

\section{Students' part-time work activities}

Nearly $80 \%$ of the UK's students work part-time alongside their full-time degree studies (Boyce and Stone, 2015). As noted, the main motivation for undertaking this work is financial, as students seek to offset tuition fees and living costs (Richardson et al., 2009; NUS, 2009). However, several studies have highlighted substantial non-financial benefits. In particular, part-time work allows students to gain insight into a job or career (Patton, 2001), become orientated to the world of work (Billet and Ovens, 2007) and, perhaps more importantly, develop the transferable skills (Holloway, 2001) that will be useful for their studies and of value to prospective employers (Wignall, 2007). 


\section{Employers' needs}

While destination data indicate that more that $71 \%$ of UK graduates are in employment six months after graduation (Prospects and AGCAS, 2015), there is still debate in the UK and elsewhere on the extent to which higher education is adequately fulfilling its role of delivering industry-ready graduates to the employment market (see, for example, Boden and Nedeva, 2010; Shafie and Nayan, 2010). While university league tables depict a range of graduate prospects from $88.3 \%$ down to $44.6 \%$ (Complete University Guide, 2016), it is increasingly evident that degree-specific knowledge is insufficient to meet the needs of many employers (Wilton, 2011; Yorke, 2004). With the exception of medicine and some other professions, the degree discipline is largely irrelevant to gaining graduate employment (Complete University Guide, 2016; Raybould and Sheedy, 2005).

However, businesses are becoming increasingly explicit about their requirements for graduate entrants, with graduates needing a range of traits, behaviours and soft skills, such as problem-solving, effective communication, team-working, etc (see Evans et al., 2015). In addition, the $21^{\text {st }}$ Century Leaders Report (CMI et al., 2014) states that employers need graduates to be able to make an effective contribution to the business from the commencement of their employment. This is particularly the case for small and medium-sized enterprises (SMEs), which must justify any investment in graduate employment as quickly as possible given their limited resources (Heaton et al., 2008). Consequently, employers, and especially SMEs, are seeking individuals with some form of work experience (High Fliers, 2016) who can thus demonstrate a broader range of work-related transferable skills.

\section{A perfect match?}

Wherever students are working part-time while studying, they have the potential to develop useful customer-facing experience and key transferable skills. At the same time, employers are seeking graduates with work experience who are able to undertake a role competently with minimal supervision and training. Thus it seems that the potential for a perfect match is emerging: companies can recruit graduates who have already acquired relevant business experience and firm cultural 
knowledge and who have developed some transferable skills which will make an immediate contribution at a lower investment in terms of money and induction time.

This approach can also remove the uncertainty associated with employing an unknown individual through a conventional recruitment process, as a relationship will have been developed with the graduate over a sustained period of part-time employment. Furthermore, students can gain leverage on the corporate ladder, which can remove the anxieties associated with applying for positions post-graduation and the uncertainties of developing a career pathway with limited organizational understanding.

\section{A perceived transient relationship?}

Richardson et al. (2009) find that university students typically work in the retail and hospitality sectors. While $12.1 \%$ of graduates find work in those sectors on completion of their degree (Prospects and AGCAS, 2015), Evans et al. (2014) found a lack of drive on the part of employers in retail and hospitality to retain the students who had worked part-time in their organization once they had graduated. In particular, Evans et al. (2014) describe one student's experience of working in a retail store while studying for a Business Management degree. Here, according to the student, there seemed to be an acceptance that students would leave to fulfil their career aspirations elsewhere. In order to pursue permanent, graduate management positions in the organization, the initiative would have to be taken by the individual student, without encouragement from the employer. Evans et al. (2014) also highlight the experience of another student, who found out about his employer's graduate development scheme only by accident when perusing the company magazine. Again, this individual confirmed that there was an expectation that students working part-time in the company would leave the organization once they graduated and it was therefore not considered worthwhile to make an effort to keep them. He felt this attitude was exacerbated because managers were frequently moved from store to store and therefore viewed staff solely as short-term resources to be used during their period in a particular store. 
Failing to encourage students who are working part-time to remain and develop their career in the organization after graduation seems to be a wasted opportunity for both the organization and the individual. A graduate with grass-roots level experience, already embedded in the company's culture, will have acquired knowledge capital of the business and its operational processes and thus will require a reduced period of induction and familiarization. Thus the business gains a quicker return on its investment, since recruitment and initial training costs are reduced, as is the uncertainty associated with recruiting a relatively unknown outside candidate (Ashton and Morton, 2005).

\section{A change of emphasis - seizing the readily-available talent}

Scott and Revis (2008) recognize the need to manage graduate talent in the hospitality sector, noting in particular the goodness of fit between graduates and the talent required by the industry. However, talent management requires that organizations manage their human assets over the long term (Salkey, 2005). According to the UK's Chartered Institute of Personnel and Development (CIPD, 2014), talent management is an all-embracing concept, which is concerned with planning, attracting, developing, retaining and evaluating talented individuals to meet the long-term objectives of the business. It is the adoption of a long-term perspective that will help organizations to move away from the notion that the relationship with student workers is a transient one and that, on the contrary, those individuals can actually support and drive strategic goals.

We do not refer here simply to staff retention, but rather to graduate retention and career progression. There is a clear opportunity to retain student workers in the organization on graduation, but it requires encouragement and incentives from the company. For example, if there is a ceiling or other limitation on progression associated with the job (as may be the case in bar work), then a progression plan will have to be created to attract the graduate.

While SMEs might not be able to match larger companies in their salary offer to graduates, Torrington et al. (2014) emphasize the importance of training and development as a strategy for retaining staff. As Garrow and Hirsh (2008) highlight, talent management forces organizations to ask what the development outcomes should be for individuals who have the potential to achieve in the 
organization. Here, SMEs can offer a bespoke and individualized training and development programme, with a greater breadth of experience - something that could be attractive to graduates seeking a career pathway.

Similarly, there is also a need for the students/graduates to push for opportunities to build on, and sell, their organizational experience, so they are perceived as worth retaining for the long term. This is becoming especially significant as graduate employment opportunities become increasingly competitive (Levy and Strick, 2016).

\section{Conclusion}

Organizations in the retail and hospitality sectors make substantial use of students to resource core operations. There is obvious potential for many more organizations to recruit undergraduate students to work part-time. Students constitute an inexpensive and flexible workforce and can offer skills and creative thinking that may benefit their employer. On the other hand, there is limited formal identification of the potential graduate leadership and management talent that might be recruited on a full-time basis from this transient part-time workforce.

Given a reasonable period of working part-time in an organization, students will develop key transferable skills sought by employers, combining the knowledge and skills developed through their chosen course with those developed (along with cultural understanding) in the employing organization. This combination can serve as an excellent grounding for moving into a graduate position to the benefit of both organization and the individual.

There are several ways in which universities and organizations can collaborate to make this seamless transition between study and employment a reality. While most courses 'allow' students to work part-time in their own time, many now include an option to undertake some form of work-based study, gaining academic credit for projects undertaken in an organizational context (whether paid or unpaid). Foundation Degrees are an obvious example of this approach, and many sandwich courses include the traditional one-year placement, usually between the second and third years of the degree programme. In addition, recent UK government initiatives to strengthen Graduate Apprenticeships 
have recognized the potential benefits of 'earn as you learn' for both undergraduate and employer. Perhaps now businesses, especially SMEs, need to take the initiative by recruiting university students to work part-time during their degree period, with a view to offering them a permanent position on graduation. This requires a longer-term perspective from both employers and individual students than is currently typical. The challenge ultimately, however, comes back to the employer to make the most of the resource at their disposal - a work-seasoned graduate who can contribute immediately on fulltime appointment, providing relevant skills and sector experience.

Nonetheless, not all jobs done on a part-time basis as a student will appeal on graduation, particularly for those graduates who wish to pursue specific professional occupations, such as law or medicine. This is especially true for the health profession, which accounts for nearly $15 \%$ of graduate leavers (Prospects and AGCAS, 2015).

In sum, we believe that both students and employers need to consider a more strategic approach to student part-time working and how it might benefit both the business and the student worker in the long term. Academic research to date on students' part-time working has focused mainly on motivations and on the impact on academic studies. How graduate career aspirations derived from part-time working potentially mesh with the needs of business requires further exploration. In particular, research regarding the attractiveness of jobs to graduates and what strategies employers might adopt to retain student workers on graduation would contribute to the growing literature on how higher education can meet the skills needs of business.

\section{References}

Ashton C and Morton L (2005) Managing talent for competitive advantage: Taking a systemic approach to talent management. Strategic HR Review 4(5): 28-31.

Billet S and Ovens C (2007) Learning about work, working life and post-school options: Guiding students reflections on paid part-time work. Journal of Education and Work 20(2): 75-90.

Boden R and Nedeva M (2010) Employing discourse: Universities and graduate employability. Journal of Education Policy 25(1) 37-54. 
Boyce L and Stone L (2015) Eight in ten students now forced to work to fund university as expected debt spirals to $£ 30,000$ for those starting studies this year [online]. Available at: http://www.thisismoney.co.uk/money/studentfinance/article-3196644/Eight-ten-studentsforced-work-fund-university-expected-debt-spirals-30-000-starting-studies-year.html (accessed 1 April 2016).

CIPD (2014) Talent management: An overview. Available at: http://www.cipd.co.uk/hrresources/factsheets/talent-management-overview.aspx (accessed 9 February 2016).

CMI, ABS and QAA (2014) 21st Century Leaders: Building Practice into the Curriculum to Boost Employability. Chartered Management Institute, Association of Business Schools and Quality Assurance Agency. Available at: https://charteredabs.org/wpcontent/uploads/2015/02/21st_century_leaders_june2014___final_report.pdf

Complete University Guide (2016) University League Tables. Available at: http://www.thecompleteuniversityguide.co.uk/ (accessed 18 March 2016).

Doughty E (2014) 40 to 1: good odds for graduate jobs? Available at: http://www.telegraph.co.uk/education/universityeducation/student-life/10967755/40-to-1good-odds-for-graduate-jobs.html (accessed 1 April 2016).

Evans C, Gbadamosi G and Richardson M (2014) Flexibility, compromise and opportunity: Students' perceptions of balancing part-time work with a full-time business degree. International Journal of Management Education 12(2): 80-90.

Evans C, Maxfield T and Gbadamosi G (2015) Using part-time working to support graduate employment aspirations: Needs and perceptions of employers Industry and Higher Education 29(4): 305-314.

Garrow V and Hirsh W (2008) Talent management: Issues of focus and fit. Public Personnel Management 37(4), 389-402.

Heaton N, McCracken M and Harrison J (2008) Graduate recruitment and development. Education + Training 50(4): 276-288. 
High Fliers (2016) The Graduate Market in 2016. London: High Fliers Research Ltd. Available at: http://www.highfliers.co.uk/download/2016/graduate market/GMReport16.pdf (accessed 1 April 2016).

Holloway JH (2001) Part-Time Work and Student Achievement. Alexandria, VA: Association for Supervision and Curriculum Development.

Levy A and Strick K (2016) Thousands of graduates in low skilled jobs: One in six accepting employment in coffee shops or call centres because they can't find work suited to their skills. Available at: http://www.dailymail.co.uk/news/article-3497853/Graduates-accepting-jobs-

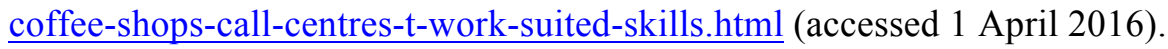

NUS Scotland (2009). Overstretched and Overdrawn: Student Hardship Survey. Edinburgh: National Union of Students Scotland. Available at: http://www.nus.org.uk/Documents/Overstretched\%20and\%20Overdrawn.pdf (accessed 1 April 2016).

Pan YJ and Lee LS (2011) Academic performance and perceived employability of graduate students in business and management: An analysis of nationwide graduate destination survey. Procedia - Social and Behavioral Sciences 25: 91-103.

Patton W (2001) Career education: What we know, what we need to know. Australian Journal of Career Development 10(3); 13-19.

Prospects and AGCAS (2015) What do graduates do? Report produced on behalf of the Higher Education Career Services Unit (HESCU). Available at: http://www.hecsu.ac.uk/current projects what do graduates do.htm (accessed 1 April 2016).

Raybould J and Sheedy V (2005) Are graduates equipped with the right skills in the employability stakes? Industrial and Commercial Training 37(4/5): 259-263.

Richardson M, Evans C and Gbadamosi G (2009) Funding full-time study through part-time work. Journal of Education and Work 22(4): 319-334.

Salkey J (2005) Talent management for the 21 st century. Strategic HR Review 4(5): 2. 
Scott B and Revis S (2008) Talent management in hospitality: Graduate career success and strategies. International Journal of Contemporary Hospitality Management 20(7): 781-791.

Shafie LA and Nayan S (2010) Employability awareness among Malaysian undergraduates. International Journal of Business and Management 5(8): 119-123.

Torrington D, Hall L, Taylor S and Atkinson C (2014) Human Resource Management 9th ed. Harlow: Pearson.

UCAS (2011) Balancing work and study. Available at:

https://www.ucas.com/ucas/undergraduate/finance-and-support/managing-money/balancingwork-and-study (accessed 1 April 2016).

Wignall A (2007) Earn while you learn and reap extra benefits. Available at:

https://www.theguardian.com/education/2007/feb/27/choosingadegree.highereducation4 (accessed 29 June 2016).

Wilton N (2011) Do employability skills really matter in the UK graduate labour market? The case of business and management graduates. Work, Employment and Society 25(1): 85-100.

Yorke M (2004) Employability in the undergraduate curriculum: Some student perspectives. European Journal of Education 39(4): 409-427. 